\title{
EFFECTS OF ALUMINUM SULPHATE, ETHANOL, SUCROSE AND THEIR COMBINATION ON THE LONGEVITY AND PHYSIOLOGICAL PROPERTIES OF ROSE (ROSA HYBRIDA L.) CUT FLOWERS
}

\author{
Hailay GEBREMEDHIN* \\ Horticulture, Adigrat University, Barlewhiti, 50, Adigrat, Ethiopia \\ Received: December 2019; Accepted: May 2020
}

\begin{abstract}
Cut rose stems were pretreated for $24 \mathrm{~h}$ with various compounds before being stored in Chrysal solution. Two experiments were conducted to study the effects of different concentrations of aluminum sulphate, ethanol and sucrose in preservative solutions and their combination on flower longevity and post-harvest physiological properties of rose (Rosa hybrida L.) cut flowers cultivars 'Red Sky' and 'Blizzard'. The first experiment aimed to determine the optimum concentration of aluminum sulphate used as a biocide $\left(0,0.5,1,1.5 \mathrm{~g} \cdot \mathrm{dm}^{-3}\right)$, ethanol used as a biocide and anti-ethylene factor $(0,4,8,12 \%)$ and sucrose used as a source of energy $\left(0,10,20,30 \mathrm{~g} \cdot \mathrm{dm}^{-3}\right)$. In the second experiment, the most effective concentrations were cumulated in combinations of pretreatment solutions. Single use of chemicals: $0.5 \mathrm{~g} \cdot \mathrm{dm}^{-3}$ aluminum sulphate, $4 \%$ ethanol and $20 \mathrm{~g} \cdot \mathrm{dm}^{-3}$ sucrose extended the longevity of both cultivars by 17,18 and $19 \%$, respectively as compared to deionized water. In the second experiment, the preservative solution containing all three chemicals at optimal concentrations extended cut flower longevity by $30 \%$ compared to deionized water. 'Blizzard' has lost its commercial value by $6.6 \%$ of the time earlier than 'Red Sky'. Generally, using a biocide, anti-ethylene and source of energy in a pretreatment solution can maintain the high quality of the cut rose flowers and their vase life.
\end{abstract}

Key words: flower quality, pretreatment solutions, vase life

\section{INTRODUCTION}

The Ethiopian flower industry started to emerge in 1992 and became the leading flower exporter in Africa. Flower production is constantly increasing, mainly for export. Ethiopia also encourages the sector to get foreign currency, youth employment and reducing poverty. Rose is the most demand cut flower worldwide and about $90 \%$ of the Ethiopian cut flower products are roses (Belwal \& Chala 2008). Due to the competitive advantage resulted from government incentives, the proximity of international markets (EU and Middle East), lots of cheap and trained employees and favorable country environments, further development of the flower industry is still expected and stimulated (Gudeta 2012).

Cut flowers have a short vase life. About 20\% of fresh flowers lose quality while passing through the market channels and plenty of remaining flowers sold at low-quality conditions dissatisfying the consumer (Mehran et al. 2007). This is mainly due to physiological and pathological problems during postharvest handling. The short vase life of cut flowers is caused by dehydration (Fanourakis et al. 2012), the adverse effects of ethylene ( $\mathrm{Wu}$ et al. 1992), and blockage of the vessels by air and microorganisms (Elhindi 2012; Elgimabi 2011; He et al. 2006). Hence, techniques are generally required to reduce microbial build-up and vascular blockage, supply energy source, increase water uptake, and arrest the negative effect of ethylene. Different commercial preparations for prolonging the vase life of cut flowers were developed (Ichimura et al. 2006). They contain silver thiosulfate (STS) as anti-ethylene, 8-hydroxyquinoline sulfate (8-HQS) as germicide and sucrose as a substrate for respiration. However, STS is criticized due to its environmental pollution and health problem (Jowkar et al. 2013a), 8-HQS is expensive to use and results in irritation of skin, eyes and respiratory tract (Anisha \& Kumar 2015). 
Previous researchers mention two components, sugar and germicide as very important (Asrar 2012; Elhindi 2012). Tsegaw et al. (2011) indicate three important ingredients of solutions to increase vase life: biocide, sugar and acidifier. Others mention ethylene as a longevity and quality factor for cut flowers (Chamani et al. 2005). Many cut flower growers in Ethiopia use 8-HQS as a germicide for all cultivars of cut roses and rarely put energy source and anti-ethylene to the holding solutions. However, it is reported that cultivars of roses have a different, genetic-driven response for preservative solutions (Ichimura et al. 2002).

The use of respiration substrates, anti-ethylene and antimicrobial chemicals with less negative health and environmental impacts have paramount importance to extend the vase life of cut flowers and increase customer satisfaction. The following solutions: aluminum sulfate $\left[\mathrm{Al}_{2}\left(\mathrm{SO}_{4}\right)_{3}\right]$ - as a biocide (Tsegaw et al. 2011; Tilahun et al. 2015), ethanol as anti-ethylene (Hajizadeh et al. 2012) and sugar (Asrar 2012; Norikoshi et al. 2016) as energy source used for short treatment before storage were reported as factors extending flower longevity and maintaining the quality of various cut flowers.

The objective of the study was to evaluate the effects of different concentrations of aluminum sulfate, ethanol and sucrose and their combinations used for 24-h pretreatment before being kept in Chrysal 500 on longevity and quality of cut rose flowers 'Red Sky' and 'Blizzard'.

\section{MATERIAL AND METHODS}

\section{Study area, experimental treatments, and design}

The study was conducted at Herburg Roses Plc, which is part of Ziway Sher Ethiopia, on rose cut flowers that were grown under greenhouse condition. It is located in the Rift valley at a latitude of $7^{\circ} 56^{\prime} \mathrm{N}$ and longitude of $38^{\circ} 43^{\prime} \mathrm{E}$. The area has an altitude of 1646 m.a.s.l. and a mean annual rainfall of $750-850 \mathrm{~mm}$. The mean maximum temperature is $28.4{ }^{\circ} \mathrm{C}$ and the minimum $14.0^{\circ} \mathrm{C}$.

The study was set in two successive experiments. The first experiment evaluated the effects of different concentrations of $\mathrm{Al}_{2}\left(\mathrm{SO}_{4}\right)_{3}\left(0.5,1,1.5 \mathrm{~g} \cdot \mathrm{dm}^{-3}\right)$, sucrose $\left(10,20,30 \mathrm{~g} \cdot \mathrm{dm}^{-3}\right)$ and ethanol (4, 8 and $\left.12 \%\right)$ and water independently on two cultivars of rose cut flowers 'Red Sky' and 'Blizzard'.
After identifying the best concentration of each chemical, the second experiment designed to evaluate the combined effects of the best concentrations. Therefore, five treatments were set labeled as T1, T2, $\mathrm{T} 3, \mathrm{~T} 4$, and $\mathrm{T} 5$ for deionized water, $\mathrm{Al}_{2}\left(\mathrm{SO}_{4}\right)_{3}+$ ethanol, $\mathrm{Al}_{2}\left(\mathrm{SO}_{4}\right)_{3}+$ sucrose, ethanol + sucrose, $\mathrm{Al}_{2}\left(\mathrm{SO}_{4}\right)_{3}$ + ethanol + sucrose, respectively for both cultivars. The concentration used for $\mathrm{Al}_{2}\left(\mathrm{SO}_{4}\right)_{3}$ was $0.5 \mathrm{~g} \cdot \mathrm{dm}^{-3}$, for ethanol was $4 \%$ and for sucrose was $20 \mathrm{~g} \cdot \mathrm{dm}^{-3}$.

\section{Experimental procedures}

Flower stems of 'Red Sky' and 'Blizzard' with red and white colors respectively, were cut from second-order emerged shoots early in the morning. Flower stems of $55 \pm 3 \mathrm{~cm}$ were harvested at typical harvest maturity when the buds were tight and sepals enclosed in the floral bud (De Capdeville et al. 2005). A day before the harvest, the plants were irrigated (Gebremedhin et al. 2013). Stems were transferred immediately to experimental solutions and kept at $3 \pm 1{ }^{\circ} \mathrm{C}$ for $24 \mathrm{~h}$. Preservative solutions were prepared using deionized water and $\mathrm{pH}$ was adjusted to 3.5-4.5 with citric acid, except for $\mathrm{Al}_{2}\left(\mathrm{SO}_{4}\right)_{3}$ solutions that were adjusted to a $\mathrm{pH}$ of 3.5 with potassium hydroxide. The bottom of flower stems were cut diagonally $(2 \mathrm{~cm})$ using a sharp cut knife prior to immersing. The prepared cut rose stems were placed in glass jars with $300 \mathrm{ml}$ volume keeping the bottom of the flower stem completely immersed.

The experimental stems (10 per each treatment) were subdivided into two groups for destructive (4 stems) and non-destructive (6 stems) sampling. After treatment with preservative solutions, the lowermost leaves were trimmed off to the height of $15 \mathrm{~cm}$ and stems were re-cut to the length of $48 \mathrm{~cm}$. After that, the flower stems were transferred to flower commercial preservative preparation Chrysal 500 at a concentration of $10 \mathrm{~g} \cdot \mathrm{dm}^{-3}$ until the completion of the experiment and maintained in vase testing room at $25 \pm 1{ }^{\circ} \mathrm{C}$ with $12 \mathrm{~h}$ of photoperiod using cool-white fluorescent lamps.

Flower longevity (FL). Decision about termination of vase life was made on the base of following parameters: visible wilting of the flowers, abscission or yellowing of more than $50 \%$ of the leaves, neck bending, abscission of more than two petals (VBN 2005). Hence, in this experiment, vase life was expressed as the number of days until the above features occur. 
Flower head diameter (FHD) was measured using Vernier caliper $(\mathrm{cm})$ at the end of the vase life day of the control flower (van Doorn \& de Witte 1991). Solution turbidity as microbial growth assessment (ST) was measured using a spectrophotometer (JENWAY 6300) at 400, 500 and $600 \mathrm{~nm}$ (Knee 2000) at the 12th day of the experiment using distilled water as a blank.

Water content ratio (WCR, g) - a dry weight of six outer petals dried to constant weight in an oven for at least 48 hours at $70{ }^{\circ} \mathrm{C}$ and calculated as described by Jones et al. (1993).

$$
\text { Water content }=\frac{\text { fresh weight }- \text { dry weight }}{\text { dry weight }}
$$

Vase solution uptake (VSU) was evaluated at the 16th day by subtracting the volume of water evaporated from a flask of the same volume without cut flower. The water loss volume was calculated by subtracting the increase in fresh weight from the water uptake volume.

$$
\mathrm{Su}=\frac{\mathrm{Su}(\mathrm{t}-1)-\mathrm{St}}{\mathrm{FWt}_{0}}(\text { Chamani et al. 2005), }
$$

where: $\mathrm{Su}$ - vase solution uptake $\left(\mathrm{ml} \cdot \mathrm{day}^{-1} \cdot \mathrm{g}\right.$ fresh weight $\left.^{-1}\right) ; \mathrm{Su}(\mathrm{t}-1)$ - solution weight $(\mathrm{g})$ of the control; $\mathrm{St}$ - solution weight $(\mathrm{g})$ at $\mathrm{t}-1,2,3$ days and so on; $\mathrm{FWt}_{0}$ - fresh weight of the stem $(\mathrm{g})$ on day 0 .

Relative fresh weight (RFW) was obtained by weighing stems before their immersion into the solutions and repeated every three days until the vase life of the control flowers were terminated. Flowers were taken out of solutions for as short time as possible (20-30 s). The fresh weight of each flower was expressed relative to the initial weight to represent the percentage of weight losses for all cut flowers tested (Joyce \& Jones 1992).

$$
\mathrm{RFW}=\frac{\mathrm{FWt}}{\mathrm{FWo}} \times 100,
$$

where: FWt - final weight of stem at different days (t), $\mathrm{FW}_{\mathrm{o}}$ - initial fresh weight and RFW - relative fresh weight.

\section{Data analysis}

Data analysis was made using the SAS statistical package (SAS Institute 2003). Both experiments were set following a completely randomized design. Each experiment was repeated twice and the average values were used for the analysis. Mean comparisons were made using the least significant difference (LSD) at $\mathrm{p}=0.05$.

\section{RESULT AND DISCUSSION}

\section{Flower longevity}

Results indicated that used separately $\mathrm{Al}_{2}\left(\mathrm{SO}_{4}\right)_{3}$, ethanol and sucrose, as well as combined preservative solutions, had a significant effect on flower longevity of rose cultivars (Table 1 \& Fig. 1). 'Red Sky' was characterized with significantly longer vase life than 'Blizzard', except when it was treated with ethanol. However, an interaction between cultivars and different concentrations of $\mathrm{Al}_{2}\left(\mathrm{SO}_{4}\right)_{3}$, sucrose and ethanol as well as their combined use did not show significant ( $p>0.05)$.

$\mathrm{Al}_{2}\left(\mathrm{SO}_{4}\right)_{3}$ at a concentration of $0.5 \mathrm{~g} \cdot \mathrm{dm}^{-3} \mathrm{ex}-$ tended the vase life of cut flower by $21 \%$ compared to distilled water (Table 1). Generally, with increasing concentration of $\mathrm{Al}_{2}\left(\mathrm{SO}_{4}\right)_{3}$, vase life decreased progressively. According to Jowkar et al. (2013b) $\mathrm{Al}_{2}\left(\mathrm{SO}_{4}\right)_{3}$ maintains membrane permeability, increases chlorophyll content and freshness of flowers and leaves of roses. De Witte et al. (2014) reported that stem bending of gerbera hastens at a high concentration of antimicrobial compounds. In the case of the ethanol, the longest vase life of cut flowers was obtained at a concentration of $4 \%$. Consistently, Podd and Van Staden (2002) found that vase life of cut flowers of carnation increased at a low concentration of ethanol. Flowers in control treatments have aged 2.7 and 1.5 days earlier than flowers treated with $4 \%$ and $8 \%$ ethanol, respectively. Similarly, Wu et al. (1992) proved that pretreatment with ethanol reduced the evolution of ethylene, reduced accumulation of ACC and completely inhibited the activity of ACC oxidase in carnation cut flower. 
Table 1. Effects of different concentration of $\mathrm{Al}_{2}\left(\mathrm{SO}_{4}\right)_{3}$, ethanol, and sucrose on flower longevity (FL), flower head diameter (FHD), solution turbidity (ST), and water content ratio of the rose cut flowers

\begin{tabular}{|c|c|c|c|c|c|c|c|c|}
\hline \multirow{3}{*}{ Factors } & \multirow{3}{*}{ Treatment } & \multirow{3}{*}{ FL (days) } & \multirow{3}{*}{ FHD $(\mathrm{cm})$} & \multirow{3}{*}{ ST } & \multicolumn{4}{|c|}{ Water content ratio $\left(\mathrm{g} \cdot \mathrm{g}^{-1}\right)$} \\
\hline & & & & & \multicolumn{4}{|c|}{ Vase life (days) } \\
\hline & & & & & $1^{\text {st }}$ & $4^{\text {th }}$ & $8^{\text {th }}$ & $12^{\text {th }}$ \\
\hline \multirow{5}{*}{$\mathrm{Al}_{2}\left(\mathrm{SO}_{4}\right)_{3}$} & water & $12.00 \mathrm{~b}$ & 7.00 & $0.07 \mathrm{a}$ & 6.82 & $5.79 b$ & $4.02 \mathrm{~b}$ & $3.12 b$ \\
\hline & $0.5 \mathrm{~g} \cdot \mathrm{dm}^{-3}$ & $14.50 \mathrm{a}$ & 6.98 & $0.05 b$ & 7.89 & $7.03 \mathrm{a}$ & $5.63 \mathrm{a}$ & $4.50 \mathrm{a}$ \\
\hline & $1.0 \mathrm{~g} \cdot \mathrm{dm}^{-3}$ & $13.00 \mathrm{~b}$ & 7.15 & $0.05 b$ & 7.89 & $6.49 \mathrm{a}$ & $4.56 \mathrm{~b}$ & $3.52 b$ \\
\hline & $1.5 \mathrm{~g} \cdot \mathrm{dm}^{-3}$ & $12.00 \mathrm{~b}$ & 6.55 & $0.04 \mathrm{~b}$ & 7.82 & $5.08 \mathrm{c}$ & $4.14 b$ & $3.26 \mathrm{~b}$ \\
\hline & $\mathrm{LSD}_{0.05}$ & 1.170 & ns & 0.01 & ns & 0.54 & 0.55 & 0.69 \\
\hline \multirow{3}{*}{ Cultivar } & 'Red Sky' & $13.67 \mathrm{a}$ & $6.41 b$ & 0.05 & $8.20 \mathrm{a}$ & $6.36 \mathrm{a}$ & 4.34 & $3.86 a$ \\
\hline & 'Blizzard' & $12.08 b$ & $7.43 \mathrm{a}$ & 0.05 & $7.01 \mathrm{~b}$ & $5.84 b$ & 4.44 & $3.34 b$ \\
\hline & $\operatorname{LSD}_{(0.05)}$ & 0.83 & 0.25 & ns & 0.78 & 0.38 & $\mathrm{~ns}$ & 0.49 \\
\hline \multicolumn{2}{|c|}{$\mathrm{Al}_{2}\left(\mathrm{SO}_{4}\right)_{3} \times$ cultivar interaction } & ns & ns & $\mathrm{ns}$ & ns & ns & $\mathrm{ns}$ & ns \\
\hline & $\mathrm{CV}(\%)$ & 7.4 & 9.3 & 18.8 & 12.0 & 7.34 & 9.8 & 15.9 \\
\hline \multirow{5}{*}{ Ethanol } & water & $12.00 \mathrm{c}$ & $7.00 \mathrm{c}$ & $0.07 \mathrm{a}$ & $6.82 b$ & $5.79 \mathrm{bc}$ & $4.02 \mathrm{~b}$ & $3.12 b$ \\
\hline & $4 \%$ & $14.67 \mathrm{a}$ & $7.93 \mathrm{a}$ & $0.06 \mathrm{~b}$ & $8.63 \mathrm{a}$ & $6.96 \mathrm{a}$ & $6.04 \mathrm{a}$ & $4.57 \mathrm{a}$ \\
\hline & $8 \%$ & $13.50 \mathrm{~b}$ & $7.47 \mathrm{~b}$ & $0.05 b$ & $8.44 \mathrm{a}$ & $6.22 \mathrm{ab}$ & $5.00 \mathrm{ab}$ & $3.21 b$ \\
\hline & $12 \%$ & $13.00 \mathrm{bc}$ & $7.26 \mathrm{bc}$ & $0.05 b$ & $6.90 \mathrm{~b}$ & $5.07 \mathrm{c}$ & $4.08 \mathrm{~b}$ & $3.19 b$ \\
\hline & $\mathrm{LSD}_{0.05}$ & 1.03 & 0.41 & 0.01 & 0.93 & 0.86 & 1.16 & 0.79 \\
\hline \multirow{3}{*}{ Cultivar } & 'Red Sky' & 13.92 & $6.66 b$ & 0.06 & 7.77 & 6.26 & 4.95 & $3.89 \mathrm{a}$ \\
\hline & 'Blizzard' & 12.67 & $8.17 \mathrm{a}$ & 0.06 & 7.62 & 5.77 & 4.62 & $3.15 b$ \\
\hline & $\mathrm{LSD}_{0.05}$ & ns & 0.29 & ns & ns & ns & ns & 0.56 \\
\hline \multicolumn{2}{|c|}{ Ethanol $\times$ cultivar interaction } & $\mathrm{ns}$ & ns & ns & ns & $\mathrm{ns}$ & ns & ns \\
\hline & CV $(\%)$ & 6.3 & 4.6 & 9.4 & 9.9 & 11.8 & 19.8 & 18.5 \\
\hline \multirow{5}{*}{ Sucrose } & water & $12.00 \mathrm{c}$ & $7.00 \mathrm{~b}$ & $0.07 \mathrm{c}$ & $6.82 b$ & $5.79 b$ & $4.02 \mathrm{~b}$ & $3.12 b$ \\
\hline & $10 \mathrm{~g} \cdot \mathrm{dm}^{-3}$ & $13.50 \mathrm{~b}$ & $7.60 \mathrm{a}$ & $0.07 \mathrm{bc}$ & $7.83 \mathrm{ab}$ & $6.33 \mathrm{ab}$ & $4.60 \mathrm{ab}$ & $3.55 \mathrm{ab}$ \\
\hline & $20 \mathrm{~g} \cdot \mathrm{dm}^{-3}$ & $14.83 \mathrm{a}$ & $8.09 \mathrm{a}$ & $0.08 \mathrm{ab}$ & $8.16 \mathrm{a}$ & $6.67 \mathrm{ab}$ & $5.39 \mathrm{a}$ & $4.21 \mathrm{a}$ \\
\hline & $30 \mathrm{~g} \cdot \mathrm{dm}^{-3}$ & $13.33 b$ & $8.19 \mathrm{a}$ & $0.09 \mathrm{a}$ & $8.36 \mathrm{a}$ & $7.26 \mathrm{a}$ & $4.60 \mathrm{a}$ & $3.25 b$ \\
\hline & $\mathrm{LSD}_{0.05}$ & 1.19 & 0.60 & 0.017 & 1.09 & 0.96 & 0.86 & 0.89 \\
\hline \multirow{3}{*}{ Cultivar } & 'Red Sky' & $13.91 \mathrm{a}$ & $7.19 b$ & $0.08 \mathrm{a}$ & 8.11 & $7.22 \mathrm{a}$ & $5.22 \mathrm{a}$ & $3.99 a$ \\
\hline & 'Blizzard' & $12.92 \mathrm{~b}$ & $8.26 \mathrm{a}$ & $0.07 b$ & 7.48 & $5.81 \mathrm{~b}$ & $4.26 \mathrm{~b}$ & $3.07 \mathrm{~b}$ \\
\hline & $\mathrm{LSD}_{0.05}$ & 0.84 & 0.42 & 0.005 & ns & 0.67 & 0.62 & 0.63 \\
\hline \multicolumn{2}{|c|}{ Sucrose $\times$ cultivar interaction } & $\mathrm{ns}$ & ns & $\mathrm{ns}$ & ns & ns & ns & ns \\
\hline & $\mathrm{CV}(\%)$ & 7.3 & 6.4 & 7.8 & 11.4 & 12.0 & 14.9 & 20.7 \\
\hline
\end{tabular}

Means in each column followed by the same letters are not significantly different at $\mathrm{p}=0.05$ for each factor; $\mathrm{CV}-$ coefficient of variance

Sucrose with a dose of $20 \mathrm{~g} \cdot \mathrm{dm}^{-3}$ resulted in the highest flower longevity by almost 3 days compared with control (Table 1). Higher $\left(30 \mathrm{~g} \cdot \mathrm{dm}^{-3}\right)$ and lower $\left(10 \mathrm{~g} \cdot \mathrm{dm}^{-3}\right)$ concentrations extended flower longevity twice less. Kumar et al. (2008) underlined that petal senescence of roses could result from sugar starvation or sugar accumulation. Sucrose acts in roses as a source of nutrition for tissues approaching carbohydrate starvation, flower opening and subsequent water relations which results in extending flower longevity (Kuiper et al. 1995). Maintaining of osmotic potential is important for extending vase life. Cut flowers of 'Red Sky' had shown longer vase life compared to 'Blizzard' when treated with $\mathrm{Al}_{2}\left(\mathrm{SO}_{4}\right)_{3}$, sucrose and their combination. Varied flower longevity could be due to different response for both 24-h pretreatment with preservative solutions and genetic status (Ichimura et al. 2002). 
Flower longevity as evaluated across two cultivars treated with combined solutions $\mathrm{T} 5, \mathrm{~T} 3, \mathrm{~T} 4$, and T2 was extended to 17.7, 16.1, 16 and 15.5 days, respectively as compared to T1, which was 12 days only (Fig. 1A). $\mathrm{Al}_{2}\left(\mathrm{SO}_{4}\right)_{3}$ was used as a biocide (Tsegaw et al. 2011), ethanol decreases ethylene production (Wu et al. 1992) and sucrose may provide the energy needed to cell function that can have a positive influence for extending the vase life. Cut flowers of 'Red Sky' evaluated across treatments finished their marketable life one day after 'Blizzard' (Fig. 1B). Generally, biocide, anti-ethylene and energy sources can be used for extension of cut flower vase life for both cultivars. Flower head diameter (FHD)

Ethanol and sucrose significantly $(\mathrm{p}<0.01)$ influenced the FHD of cut roses (Table 1). The best effect was obtained with $4 \%$ ethanol and $30 \mathrm{~g} \cdot \mathrm{dm}^{-3}$ sucrose. The combined effects of preservative solutions were significant $(\mathrm{p}<0.001)$ for FHD (Fig. 1). The most effective was combination T4 (ethanol + sucrose) and T5 (all three components). The double advantage of reducing microbial load and reducing ethylene production might help to enhance the flower opening. The addition of sucrose increased FHD comparing with control. Van Doorn and de Witte (1991) reported that the flower opening of cut roses depends on the carbohydrate content in petals. In addition, Norikoshi et al. (2016) confirmed that sucrose promotes cell expansion and petals markedly curved outward. However, good flower opening does not guarantee to extend flower longevity. Knee (2000) stated that sugar encourages the multiplication of bacteria, which eventually block xylem vessels.
FHD were significantly $(\mathrm{p}<0.05)$ lowest in control compared to the other treatments (Fig. 1 A). Ichimura et al. (2005) reported variation in FHD among rose cultivars. Good flower bud expansion in solutions containing sucrose may be due to turgor pressure maintenance. A combination of sugar and germicide promotes petal growth of Antirrhinum (Asrar 2012) and rose (Norikoshi et al. 2016). Therefore, flower opening can be enhanced using germicides and sugars together in concentrations depending on cultivar.

\section{Solution turbidity (ST)}

Effects of different concentrations of $\mathrm{Al}_{2}\left(\mathrm{SO}_{4}\right)_{3}$, ethanol, sucrose and their combinations showed significant ( $p$ < 0.05) effects on ST. Nevertheless, interaction effects between cultivar and concentration were non-significant, except for $30 \mathrm{~g} \cdot \mathrm{dm}^{-3}$ sucrose (Table 1). Taking the measurements on day 12 th, the interaction effects of combined preservative treatments and cultivars were significant $(\mathrm{p}<0.05)$ for ST (Table 2).

Flowers not treated with preservative solutions showed the highest values of ST and the lowest value was recorded in cut flowers treated with all three components (Table 2). The low turbidity of vase solution may be due to the biocidal and disinfectant properties of $\mathrm{Al}_{2}\left(\mathrm{SO}_{4}\right)_{3}$ and ethanol, suppressing microbial development. Both cultivars had shown similar solution clarity under different concentrations of $\mathrm{Al}_{2}\left(\mathrm{SO}_{4}\right)_{3}$ and ethanol. Conversely, the addition of sucrose only to the vase solution of flowers increased the ST and the highest value was obtained at the $30 \mathrm{~g} \cdot \mathrm{dm}^{-3}$ sucrose (Table 1). It is in harmony with the results of Knee (2000).

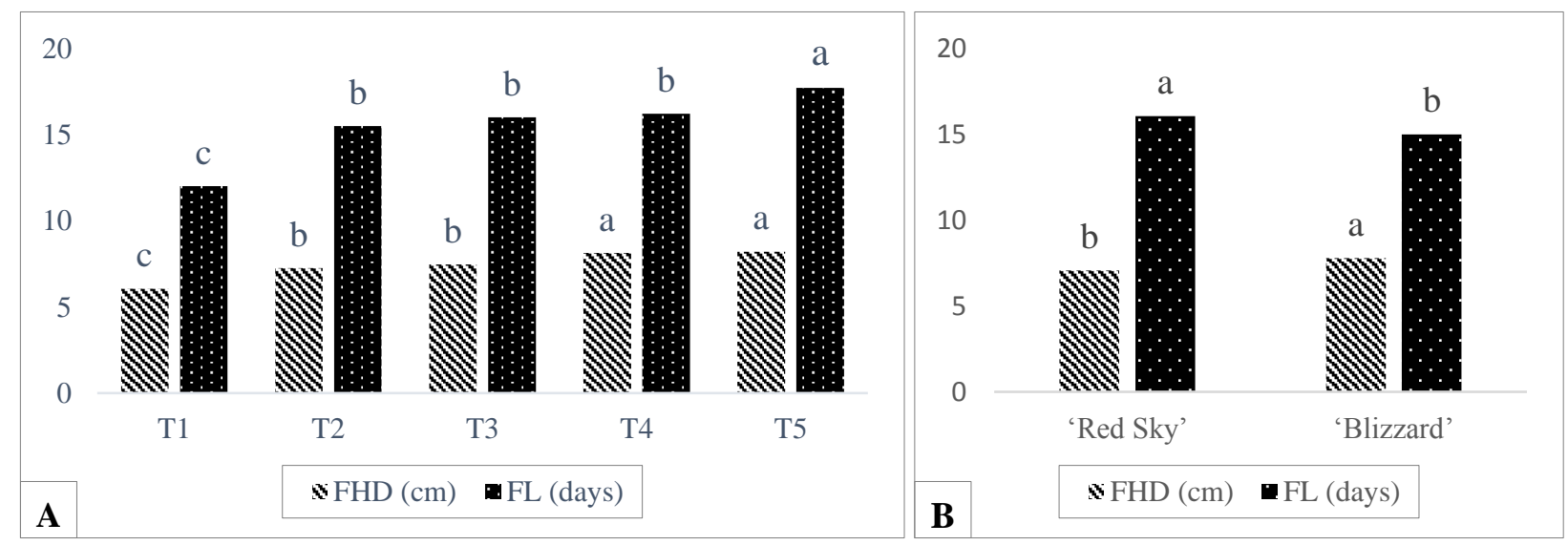

Fig. 1. Effects of different solutions used for 24-h treatment (A) and cultivars (B) on flower head diameter (FHD) and flower longevity. Means that do not differ significantly from each other at the $p=0.05$ are illustrated with the same letter on the bar graph 
Table 2. Effects of 24-h treatment with different solutions and cultivars on solution turbidity and solution uptake

\begin{tabular}{|c|c|c|c|c|c|c|c|c|c|c|}
\hline \multirow{3}{*}{ Cultivars } & \multicolumn{5}{|c|}{ Solution turbidity (on day $12^{\text {th }}$ ) } & \multicolumn{5}{|c|}{ Solution uptake (on day $16^{\text {th }}$ ) } \\
\hline & \multicolumn{10}{|c|}{ 24-h solutions treatments } \\
\hline & $\mathrm{T} 1$ & $\mathrm{~T} 2$ & T3 & $\mathrm{T} 4$ & T5 & $\mathrm{T} 1$ & $\mathrm{~T} 2$ & T3 & $\mathrm{T} 4$ & T5 \\
\hline 'Red Sky' & $0.08 \mathrm{a}$ & $0.05 \mathrm{de}$ & $0.06 \mathrm{~cd}$ & $0.068 \mathrm{bc}$ & $0.047 \mathrm{e}$ & - & $0.23 \mathrm{c}$ & $0.23 c$ & $0.27 \mathrm{ab}$ & $0.29 \mathrm{a}$ \\
\hline 'Blizzard' & $0.07 \mathrm{ab}$ & $0.05 \mathrm{de}$ & $0.07 \mathrm{ab}$ & $0.065 b c$ & $0.053 \mathrm{de}$ & - & $0.16 \mathrm{e}$ & $0.19 \mathrm{~d}$ & $0.16 \mathrm{e}$ & $0.27 \mathrm{ab}$ \\
\hline LSD & & & 0.06 & & & & & 0.02 & & \\
\hline $\begin{array}{l}\mathrm{p} \text {-values of PS } \times \\
\text { cultivar interaction }\end{array}$ & \multicolumn{5}{|c|}{0.003} & \multicolumn{5}{|c|}{0.004} \\
\hline $\mathrm{CV}$ & \multicolumn{5}{|c|}{15} & \multicolumn{5}{|c|}{8.5} \\
\hline
\end{tabular}

Means followed by the same letters are not significantly different at the $\mathrm{p}=0.05,-$ no data since vase life ended on the 12 th day

Table 3. Effects of 24-h treatment with different solutions and cultivars on water content ratio $\left(\mathrm{g} \cdot \mathrm{g}^{-1}\right)$ in outer petals

\begin{tabular}{|c|c|c|c|c|c|c|}
\hline \multirow{2}{*}{ Factors } & \multirow{2}{*}{ Combinations } & \multicolumn{5}{|c|}{ Days of experiment } \\
\hline & & 1 & 4 & 8 & 12 & 16 \\
\hline \multirow{6}{*}{ Solutions } & $\mathrm{T} 1$ & $5.9 \mathrm{c}$ & $5.1 \mathrm{c}$ & $4.1 \mathrm{c}$ & $3.3 \mathrm{c}$ & - \\
\hline & $\mathrm{T} 2$ & $7.5 \mathrm{ab}$ & $6.9 \mathrm{~b}$ & $5.6 \mathrm{ab}$ & $5.3 b$ & $3.7 \mathrm{~b}$ \\
\hline & T3 & $7.4 \mathrm{ab}$ & $6.5 b$ & $5.2 \mathrm{~b}$ & $4.9 \mathrm{~b}$ & $3.8 \mathrm{~b}$ \\
\hline & $\mathrm{T} 4$ & $7.2 \mathrm{~b}$ & $6.5 b$ & $5.2 b$ & $5.7 b$ & $3.8 b$ \\
\hline & T5 & $8.3 \mathrm{a}$ & $8.1 \mathrm{a}$ & $6.2 \mathrm{a}$ & $6.8 \mathrm{a}$ & $4.5 \mathrm{a}$ \\
\hline & $\mathrm{LSD}_{0.05}$ & 1 & 1.1 & 0.9 & 1 & 0.5 \\
\hline \multirow{3}{*}{ Cultivars } & 'Red Sky' & $7.8 \mathrm{a}$ & 7.2 & $5.7 \mathrm{a}$ & $5.7 \mathrm{a}$ & 4.1 \\
\hline & 'Blizzard' & $6.7 b$ & 6.0 & $4.8 \mathrm{~b}$ & $4.7 b$ & 3.9 \\
\hline & $\mathrm{LSD}_{0.05}$ & 0.6 & ns & 0.6 & 0.6 & ns \\
\hline \multicolumn{2}{|c|}{ Solution $\times$ cultivar interaction } & ns & ns & ns & ns & ns \\
\hline & $\mathrm{CV}(\%)$ & 11.8 & 14.5 & 15 & 16.2 & 10.9 \\
\hline
\end{tabular}

Means followed by the same letters are not significantly different at the $\mathrm{p}=0.05,-$ no data since vase life ended on the 12 th day

\section{Water content ratio (WCR)}

Results depicted that applications of different concentrations of chemicals and their combinations had significant $(p<0.05)$ effects on WCR. 'Red Sky' plants showed significantly $(p<0.01)$ higher WCR compared to 'Blizzard'. Interaction effects of different concentrations and combinations of chemicals with cultivars were non-significantly different $(\mathrm{p}<0.05)$ for WCR in all terms (Table 1). On 8th and 12th day, the highest WCR in petals was recorded in flowers treated with $0.5 \mathrm{~g} \cdot \mathrm{dm}^{-3} \mathrm{Al}_{2}\left(\mathrm{SO}_{4}\right)_{3}, 4 \%$ of ethanol and $20 \mathrm{~g} \cdot \mathrm{dm}^{-3}$ sucrose. 'Red Sky' plants showed significantly higher water content ratio compared to 'Blizzard'. The lowest water content was recorded in control treatment compared to sucrose solutions. Generally, WCR progressively decreases over time until the end of the experiment. It was in accordance with Hajizadeh et al. (2012). The highest WCR showed shoots at T5 treatment (Table 3), which indicates the important role of all three components in preservative solution due to balancing the osmotic relation and reducing tissue drying. 'Blizzard' plants had shown significantly lower water content compared to 'Red Sky' on 1st, 8th and 12th day of experiment (Table 3). Maintaining optimal water balance is a fundamental objective of cut flower handling (Kumar et al. 2008).

\section{Vase solution uptake (VSU)}

Different concentrations of $\mathrm{Al}_{2}\left(\mathrm{SO}_{4}\right)_{3}$, ethanol and sucrose had resulted in significantly $(\mathrm{p}<0.05)$ different solution uptake. However, the interaction effect of all concentrations of individually applied chemicals with cultivars had no significant ( $p>0.05$ ) effect on solution uptake (Table 4). Combined effects of used components were statistically significant for solution uptake on the 4th, 8th, and 12th day of experiment (Fig. 2A). The highest uptake for all three terms of measurement was in the treatment T5. The differences were especially visible on the 12th day. However, the interaction of combined chemicals and cultivars was significant only on the 16th vase life day (Table 2). 
In the current results, the enhancement of solution uptake was associated with specific concentrations. The most optimal were $0.5 \mathrm{~g} \cdot \mathrm{dm}^{-3}$ aluminum sulfate, $4 \%$ of ethanol and $10 \mathrm{~g} \cdot \mathrm{dm}^{-3}$ sucrose (Table 4). Generally, solution uptake decreased with prolonging of storage that could be due to air embolism of cut stem, a proliferation of microbes, and plant reaction to wounding (Tsegaw et al. 2011).

Solution uptake and transpiration rates determine the vase life termination of cut flowers (van Doorn \& de Witte 1991). Similarly, vascular blockage in the lowermost segment of the stem can result in lower water potential and low transpiration stream so that loss turgidity. Therefore, the use of biocides reduces stem plugging (de Witte et al. 2014; Asrar 2012; van Doorn \& de Witte 1991). Phytotoxic effects of some biocides can also shorten the vase life of roses (de Witte et al. 2014; Knee 2000), therefore determining appropriate concentration is vital.

Table 4. Effects of different concentrations of $\mathrm{Al}_{2}\left(\mathrm{SO}_{4}\right)_{3}$, ethanol and sucrose on solution uptake and relative fresh weight of cut flowers of rose cultivars

\begin{tabular}{|c|c|c|c|c|c|c|c|c|c|}
\hline \multirow{3}{*}{ Factors } & \multirow{3}{*}{ Treatment } & \multicolumn{5}{|c|}{ Vase solution uptake $\left(\mathrm{ml} \cdot \mathrm{day}^{-1} \cdot \mathrm{g}^{-1}\right)$} & \multicolumn{3}{|c|}{ Relative fresh weight $(\%)$} \\
\hline & & \multicolumn{8}{|c|}{ day of experiment } \\
\hline & & $1^{\text {st }}$ & $4^{\text {th }}$ & $8^{\text {th }}$ & $12^{\text {th }}$ & $1^{\text {st }}$ & $4^{\text {th }}$ & $8^{\text {th }}$ & $12^{\text {th }}$ \\
\hline \multirow{5}{*}{$\mathrm{Al}_{2}\left(\mathrm{SO}_{4}\right)_{3}$} & Water & 0.31 & $0.24 b$ & $0.21 b$ & $0.20 \mathrm{~b}$ & 101.79 & $91.12 b$ & $83.87 b$ & $67.86 \mathrm{c}$ \\
\hline & $0.5 \mathrm{~g} \cdot \mathrm{dm}^{-3}$ & 0.40 & $0.30 \mathrm{a}$ & $0.28 \mathrm{a}$ & $0.25 \mathrm{a}$ & 109.01 & $100.72 \mathrm{a}$ & $93.86 \mathrm{a}$ & $83.55 \mathrm{a}$ \\
\hline & $1 \mathrm{~g} \cdot \mathrm{dm}^{-3}$ & 0.38 & $0.28 \mathrm{ab}$ & $0.23 b$ & $0.21 b$ & 104.34 & $91.88 b$ & $86.27 b$ & $76.27 \mathrm{~b}$ \\
\hline & $1.5 \mathrm{~g} \cdot \mathrm{dm}^{-3}$ & 0.37 & $0.24 \mathrm{~b}$ & $0.21 b$ & $0.20 \mathrm{~b}$ & 101.95 & $90.78 b$ & $82.19 b$ & $69.56 \mathrm{c}$ \\
\hline & $\mathrm{LSD}_{0.05}$ & ns & 0.05 & 0.04 & 0.04 & ns & 6.48 & 6.87 & 6.26 \\
\hline \multirow{3}{*}{ Cultivars } & 'Red Sky' & 0.38 & 0.26 & 0.23 & 0.21 & 103.44 & 94.03 & 85.52 & 75.27 \\
\hline & 'Blizzard' & 0.35 & 0.27 & 0.24 & 0.22 & 105.11 & 93.16 & 87.58 & 73.38 \\
\hline & $\mathrm{LSD}_{0.05}$ & ns & ns & ns & ns & ns & $\mathrm{ns}$ & ns & ns \\
\hline \multicolumn{2}{|c|}{$\mathrm{Al}_{2}\left(\mathrm{SO}_{4}\right)_{3} \times$ cultivar interaction } & ns & ns & ns & ns & ns & ns & ns & ns \\
\hline & $\mathrm{CV}$ & 11.6 & 15.5 & 17.2 & 15.2 & 6.9 & 5.7 & 6.5 & 6.9 \\
\hline \multirow{5}{*}{ Ethanol } & Water & $0.31 b$ & $0.24 b$ & $0.21 \mathrm{c}$ & $0.20 \mathrm{~b}$ & 101.78 & $91.02 \mathrm{~b}$ & $83.87 b$ & $67.86 \mathrm{c}$ \\
\hline & $4 \%$ & $0.39 a$ & $0.31 \mathrm{a}$ & $0.29 a$ & $0.27 \mathrm{a}$ & 108.14 & $102.04 \mathrm{a}$ & $97.76 \mathrm{a}$ & $82.60 \mathrm{a}$ \\
\hline & $8 \%$ & $0.37 \mathrm{a}$ & $0.28 \mathrm{a}$ & $0.26 a b$ & $0.25 a$ & 104.42 & $98.76 a$ & $93.11 \mathrm{a}$ & $74.92 b$ \\
\hline & $12 \%$ & $0.37 \mathrm{a}$ & $0.23 \mathrm{a}$ & $0.22 \mathrm{c}$ & $0.20 \mathrm{~b}$ & 107.70 & $98.42 \mathrm{a}$ & $92.85 \mathrm{a}$ & $75.16 \mathrm{~b}$ \\
\hline & $\mathrm{LSD}_{0.05}$ & 0.04 & 0.04 & 0.04 & 0.04 & ns & 6.68 & 7.83 & 6.87 \\
\hline \multirow{3}{*}{ Cultivars } & 'Red Sky' & 0.36 & 0.27 & 0.24 & 0.23 & 107.10 & 97.21 & 91.53 & 75.15 \\
\hline & 'Blizzard' & 0.35 & 0.29 & 0.25 & 0.23 & 103.92 & 97.91 & 92.26 & 75.12 \\
\hline & $\mathrm{LSD}_{0.05}$ & ns & ns & ns & ns & ns & ns & ns & ns \\
\hline \multicolumn{2}{|c|}{ Ethanol $\times$ cultivar interaction } & ns & ns & ns & ns & ns & ns & ns & ns \\
\hline & $\mathrm{CV}$ & 8.7 & 13.7 & 14.6 & 16.4 & 6.9 & 5.6 & 7.0 & 7.5 \\
\hline \multirow{5}{*}{ Sucrose } & Water & $0.31 b$ & $0.24 \mathrm{c}$ & $0.21 b$ & $0.20 \mathrm{ab}$ & $88.96 b$ & $79.12 b$ & $75.99 b$ & $68.31 \mathrm{c}$ \\
\hline & $10 \mathrm{~g} \cdot \mathrm{dm}^{-3}$ & $0.40 \mathrm{a}$ & $0.32 b$ & $0.26 \mathrm{a}$ & $0.23 \mathrm{a}$ & $116.76 \mathrm{a}$ & $105.16 \mathrm{a}$ & $89.62 b$ & $81.40 \mathrm{~b}$ \\
\hline & $20 \mathrm{~g} \cdot \mathrm{dm}^{-3}$ & $0.41 \mathrm{a}$ & $0.35 \mathrm{a}$ & $0.25 \mathrm{a}$ & $0.23 \mathrm{a}$ & $110.28 \mathrm{a}$ & $103.81 \mathrm{a}$ & $107.26 \mathrm{a}$ & $93.91 \mathrm{a}$ \\
\hline & $30 \mathrm{~g} \cdot \mathrm{dm}^{-3}$ & $0.42 \mathrm{a}$ & $0.35 \mathrm{a}$ & $0.24 \mathrm{a}$ & $0.17 \mathrm{~b}$ & $110.29 \mathrm{a}$ & $105.28 \mathrm{a}$ & $109.80 \mathrm{a}$ & $97.44 \mathrm{a}$ \\
\hline & $\mathrm{LSD}_{0.05}$ & 0.03 & 0.03 & 0.03 & 0.04 & 6.84 & 8.19 & 15.75 & 11.72 \\
\hline \multirow{3}{*}{ Cultivars } & 'Red Sky' & $0.41 \mathrm{a}$ & 0.31 & 0.23 & 0.21 & 104.63 & 100.39 & 97.64 & 86.18 \\
\hline & 'Blizzard' & $0.30 \mathrm{~b}$ & 0.31 & 0.24 & 0.21 & 108.52 & 96.29 & 93.70 & 84.35 \\
\hline & $\mathrm{LSD}_{0.05}$ & 0.02 & ns & $\mathrm{ns}$ & ns & $\mathrm{ns}$ & ns & ns & $\mathrm{ns}$ \\
\hline \multicolumn{2}{|c|}{ Sucrose $\times$ cultivar interaction } & $\mathrm{ns}$ & ns & ns & ns & ns & ns & ns & ns \\
\hline & $\mathrm{CV}$ & 8.5 & 8.3 & 10.8 & 15.5 & 5.2 & 6.8 & 13.5 & 11.2 \\
\hline
\end{tabular}

Means in each column followed by the same letters are not significantly different at the $\mathrm{p}=0.05$ for each factor 


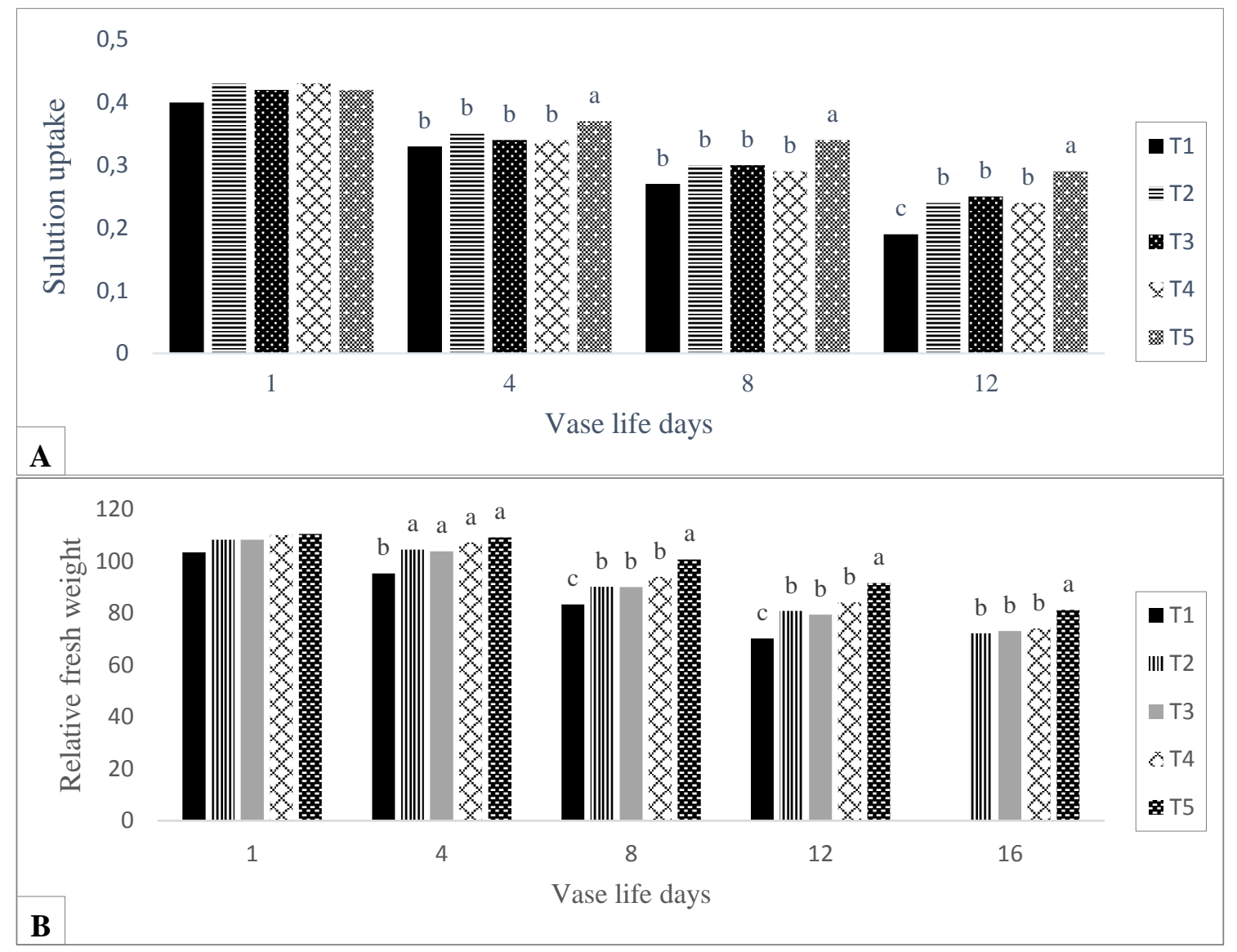

Fig. 2. Effects of different preservative solutions on solution uptake (A) and relative fresh weight (B) of rose cut flowers. Means that do not differ significantly from each other at the $\mathrm{p}=0.05$ are illustrated with the same letter on the bar graph
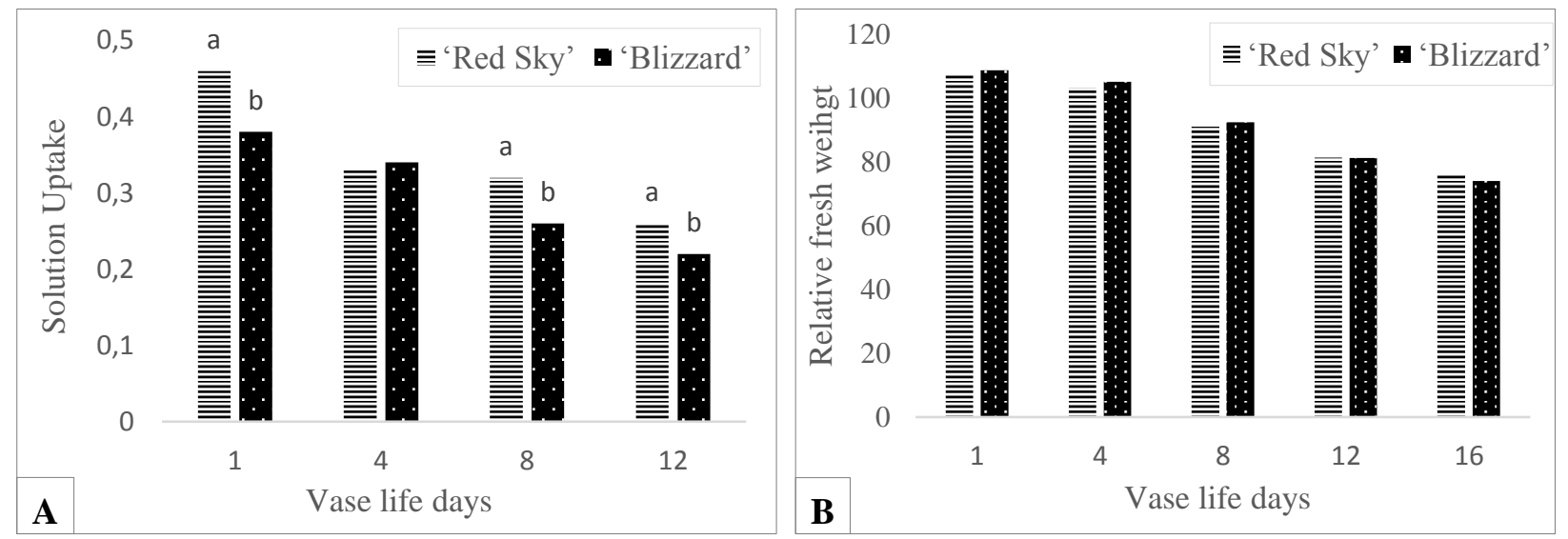

Fig. 3. Effects of different preservative solutions on solution uptake (A) and relative fresh weight (B) of rose cut flowers. Means that do not differ significantly from each other at the $\mathrm{p}=0.05$ are illustrated with the same letter on the bar graph

\section{Relative fresh weight (RFW)}

RFW decreased with time of storage in both cultivars (Table 4, Fig. 2B). The concentrations of $\mathrm{Al}_{2}\left(\mathrm{SO}_{4}\right)_{3}$, ethanol and sucrose had significant $(p<0.05)$ effects on RFW on the 4th, 8th and 12th day of the experiment (Table 4). Optimum concentrations for RFW were generally the same as for solution uptakes, but also the highest values were scored at higher concentrations of 
ethanol and sucrose. Reduction in RFW loss could be the result of the anti-microbial property of ethanol and $\mathrm{Al}_{2}\left(\mathrm{SO}_{4}\right)_{3}$ that reduces the microbial proliferation in the storage solutions and basal parts of the stems and increases the hydraulic conductance.

Referred here our results concerning RFW are in agreement with those of Ichimura et al. (2002) that observed that RFW loss was delayed in 'Noblesse' and 'Sonia' cultivars when treated with sucrose. Norikoshi et al. (2016) reported that sucrose treatment increased the volume of the vacuole, cell wall and air space in cut rose flowers. All pre-treatments affected significantly ( $\mathrm{p}<0.05)$ RFW of both cultivars comparing with control (Fig. 2B) and no differences between cultivars were found across treatments (Fig. 3B). Combinations of the three chemicals (T5) at optimal concentrations shown the highest RFW.

\section{CONCLUSION}

24-hours treatment of rose stems with one of the following preservative chemicals: $0.5 \mathrm{~g} \cdot \mathrm{dm}^{-3}$ $\mathrm{Al}_{2}\left(\mathrm{SO}_{4}\right)_{3}, 4 \%$ ethanol or $20 \mathrm{~g} \cdot \mathrm{dm}^{-3}$ sucrose as a single and in combined solution were the most effective for extending the vase life of cut rose cultivars 'Red Sky' and 'Blizzard'. As a single, they increased stems' longevity by 2.5 to 2.8 days as compared to the control (distillate water) and by 5.7 days when used in a combined solution. Such a composition of the preservative solution resulted in the highest solution uptake and water content in petals. The longevity of 'Red Sky' was greater than 'Blizzard'.

\section{REFERENCES}

Anisha P.N., Kumar S. 2015. Assessment of betel leaf extract and 8-HQC on keeping quality and vase life of flowers of rose cvs. Konfetti and Bordeaux. Journal of Ornamental Horticulture 18(3-4): 112-117.

Asrar A.W.A. 2012. Effects of some preservative solutions on vase life and keeping quality of snapdragon (Antirrhinum majus L.) cut flowers. Journal of the Saudi Society of Agricultural Sciences 11: 29-35. DOI: 10.1016/j.jssas.2011.06.002.

Belwal R., Chala M. 2008. Catalysts and barriers to cut flower export: A case study of Ethiopian floriculture industry. International Journal of
Emerging Markets 3(2): 216-235. DOI: 10.1108/17468800810862650.

Chamani E., Khalighi A., Joyce D.C., Irving D.E., Zamani Z.A., Mostofi Y., Kafi M. 2005. Ethylene and anti-ethylene treatment effects on cut 'First Red' rose. Journal of Applied Horticulture 7(1): 3-7. DOI: 10.37855/jah.2005.v07i01.01.

De Capdeville G., Maffia L.A., Finger F.L., Batista U.G. 2005. Pre-harvest calcium sulfate applications affect vase life and severity of gray mold in cut roses. Scientia Horticulturae 103(3): 329-338. DOI: 10.1016/j.scienta.2004.06.016.

van Doorn W.G., de Witte 1991. Effect of bacterial suspensions on vascular occlusion in stems of cut rose flowers. Journal of Applied Bacteriology 71: 119123. DOI: 10.1111/j.1365-2672.1991.tb02965.x.

Elgimabi M. 2011. Vase life extension of rose cut flowers (Rosa hybrida) as influenced by silver nitrate and sucrose pulsing. American Journal of Agricultural and Biological Sciences 6(1): 128-133. DOI: 10.3844/ajabssp.2011.128.133.

Elhindi K.M. 2012. Effects of postharvest pretreatments and preservative solutions on vase life longevity and flower quality of sweet pea (Lathyrus odoratus L.). Photosynthetica 50(3): 371-379. DOI: 10.1007/s11099-012-0053-3.

Fanourakis D., Carvalho D.R.A., Gitonga V.W., Van Heusden A.W., Almeida D.P.F., Heuvelink E., Carvalho S.M.P. 2012. Breeding cut roses for better keeping quality: first steps. Acta Horticulturae 937: 875-882. DOI: 10.17660/actahortic.2012.937.107.

Gebremedhin H., Tesfaye B., Mohammed A., Tsegay D. 2013. Influence of preservative solutions on vase life and postharvest characteristics of rose (Rosa hybrid) cut flowers. International Journal of Biotechnology and Molecular Biology Research 4(8): 111-118. DOI: 10.5897/ijbmbr2013.0171.

Gudeta D.T. 2012. Socio-economic and Environmental Impact of Floriculture Industry in Ethiopia. Thesis, Humboldt University of Berlin, Germany, $55 \mathrm{p}$.

Hajizadeh H.S., Farokhzad A., Chelan V.G. 2012. Using of preservative solutions to improve postharvest life of Rosa hybrid cv. Black Magic. Journal of Agricultural Technology 8(5): 1801-1810.

He S., Joyce D.C., Irving D.E., Faragher J.D. 2006. Stem end blockage in cut Grevillea 'Crimson Yullo' inflorescences. Postharvest Biology and Technology 41(1): 78-84. DOI: 10.1016/j.postharvbio.2006.03.002.

Ichimura K., Kawabata Y., Kishimoto M., Goto R., Yamada K. 2002. Variation with the cultivar in the 
vase life of cut rose flowers. Bulletin of the National Institute of Floricultural Science 2: 9-20.

Ichimura K., Kishimoto M., Norikoshi R., Kawabata Y., Yamada K. 2005. Soluble carbohydrates and variation in vase-life of cut rose cultivars 'Delilah' and 'Sonia'. Journal of Horticultural Science and Biotechnology 80(3): 280-286. DOI: 10.1080/14620316.2005.11511930.

Ichimura K., Taguchi M., Norikoshi R. 2006. Extension of the vase life in cut roses by treatment with glucose, isothiazolinonic germicide, citric acid and aluminum sulphate solution. Japan Agricultural Research Quarterly 40(3): 263-269. DOI: 10.6090/jarq.40.263.

Jones R.B., Faragher J.D., van Doorn W.G. 1993. Water relations of cut flowering branches of Thryptomene calycina (Lindl.) Stapf. (Myrtaceae). Postharvest Biology and Technology 3: 57-67. DOI: 10.1016/0925-5214(93)90027-z.

Jowkar M.M., Khalighi A., Kafi M., Hassanzadeh N. 2013a. Evaluation of aluminium sulfate as vase solution biocide on postharvest microbial and physiological properties of 'Cherry Brandy' rose. Acta Horticulturae 1012: 615-626. DOI: 10.17660/actahortic.2013.1012.83.

Jowkar M.M., Khalighi A., Kafi M., Hassanzadeh N. 2013b. Nano silver application impact as vase solution biocide on postharvest microbial and physiological properties of 'Cherry Brandy' rose. Journal of Food, Agriculture and Environment 11: 1045-1050.

Joyce D.C., Jones P.N. 1992. Water balance of the foliage of cut Geraldton wax flower. Postharvest Biology and Technology 2: 31-39. DOI: 10.1016/09255214(92)90025-k.

Knee M. 2000. Selection of biocides for use in floral preservatives. Postharvest Biology and Technology 18(3): 227-234. DOI: 10.1016/s0925-5214(99)00074-5.

Kuiper D., Ribot S., van Reenen H.S., Marissen N. 1995. The effect of sucrose on the flower bud opening of 'Madelon' cut roses. Scientia Horticulturae 60: 325-336. DOI: 10.1016/0304-4238(94)00706-1.
Kumar N., Srivastava G.C., Dixit K. 2008. Effect of ethanol plus sucrose on the vase-life of cut rose (Rosa hybrida L.). Journal of Horticultural Science and Biotechnology 83:6: 749-754. DOI: 10.1080/14620316.2008.11512455.

Mehran A., Hossein D.G., Tehranifar A. 2007. Effects of pre-harvest calcium fertilization on vase life of rose cut flowers cv. Alexander. Acta Horticulturae 804: 215-218. DOI: 10.17660/actahortic.2008.804.28.

Norikoshi R., Shibata T., Niki T., Ichimura K. 2016. Sucrose treatment enlarges petal cell size and increases vacuolar sugar concentrations in cut rose flowers. Postharvest Biology and Technology 116: 59-65. DOI: 10.1016/j.postharvbio.2016.01.003.

Podd L.A., Van Staden J. 2002. Physiological response and extension of vase life of cut carnation flowers treated with ethanol and acetaldehyde. I. Chlorophyll content and carbohydrate status. Plant Growth Regulation 38(2): 99-105. DOI: 10.1023/a:1021267712167.

Tilahun S., Soon J.C., Su P.D. 2015. Influence of pulsing biocides on vase life of cut roses (Rosa hybrida L.). Science, Technology and Arts Research Journal 4(3): 79-82. DOI: 10.4314/star.v4i3.12.

Tsegaw T., Tilahun S., Humphries G. 2011. Influence of pulsing biocides and preservative solution treatment on the vase life of cut rose (Rosa hybrida L.) varieties. Ethiopian Journal of Applied Science and Technology 2(2): 1-15.

VBN 2005. Evaluation Cards for Cut Flowers. Vereniging van Bloemenveilingen in Nederland, Leiden, the Netherlands.

de Witte Y., Harkema H., van Doorn W.G. 2014. Effect of antimicrobial compounds on cut Gerbera flowers: Poor relation between stem bending and numbers of bacteria in the vase water. Postharvest Biology and Technology 91: 78-83. DOI: 10.1016/j.postharvbio.2013.12.018.

Wu M.J., Zacarias L., Saltveit M.E., Reid M.S. 1992. Alcohols and carnation senescence. HortScience 27: 136-138. DOI: 10.21273/hortsci.27.2.136. 